\title{
PEMBELAJARAN BERBASIS PROYEK UNTUK MENINGKATKAN KETERAMPILAN PROSES SAINS DAN PENGUASAAN KONSEP SISWA SMKN KEHUTANAN PROVINSI RIAU \\ PADA MATERI PEMISAHAN CAMPURAN
}

\author{
Sri Rahmadani ${ }^{1}$, Sri Wilda Albeta ${ }^{2)}$ \\ ${ }^{1)}$ SMKN Negeri Pertanian Terpadu Provinsi Riau \\ ${ }^{2)}$ Prodi Pendidikan Kimia FKIP Universitas Riau \\ Email: srirahmadani86@gmail.com
}

\begin{abstract}
This study aims to look at improving science process skills and mastering the concepts of students using project-based learning on mixed separation. The research method used is Weak Experimental One Group Pretest-Postest Design. The object of this research is the tenth grade students of the Riau Province Forestry Vocational High School. The object of this research is the tenth grade students of the Riau Province Forestry Vocational High School. The data analysis technique used in this study is descriptive statistical analysis, namely by calculating the percentage aspects of student KPS (predicting, grouping, applying concepts, communicating, observing, designing experiments) which have implications for improving students' mastery of concepts. The KPS aspect of students who experienced the highest increase was the aspect of classifying by $97 \%$, while the lowest was achieved in the aspect of applying the concept by $54 \%$. There was an increase in mastery of the concept of mixed separation by $66.6 \%$ with the medium category. Thus it can be concluded that project-based learning can improve science process skills and mastery of students' concepts on mixed separation.
\end{abstract}

Key words : Project-Based Learning, science process skills, mastery of the concept, the Separation of Mixtures Study.

\footnotetext{
Abstrak

Penelitian ini bertujuan untuk melihat peningkatan keterampilan proses sains dan penguasaan konsep siswa menggunakan pembelajaran berbasis proyek pada materi pemisahan campuran. Metode yang digunakan adalah Weak Experimental One Group Pretest-Postest Design. Objek penelitian adalah siswa kelas X SMKN Kehutanan
} 
Provinsi Riau. Teknik analisis data yang digunakan adalah analisis statistik deskriptif, dengan cara menghitung persentase aspek keterampilan proses sains siswa (memprediksi, mengelompokkan, menerapkan konsep, berkomunikasi, observasi, merancang percobaan) yang berimplikasi pada peningkatan penguasaan konsep siswa. Aspek keterampilan proses sains siswa yang mengalami peningkatan tertinggi adalah aspek mengelompokkan sebesar 97\%, dan terendah dicapai pada aspek menerapkan konsep sebesar 54\% serta peningkatan penguasaan konsep pemisahan campuran sebesar $66,6 \%$ dengan kategori sedang. Dapat disimpulkan bahwa pembelajaran berbasis proyek dapat meningkatkan keterampilan proses sains dan penguasaan konsep siswa pada materi pemisahan campuran.

Kata Kunci: Pembelajaran berbasis proyek, keterampilan proses sains, penguasaan konsep, materi pemisahan campuran.

\section{PENDAHULUAN}

Ilmu Pengetahuan Alam (IPA) berkaitan dengan cara mencari tahu tentang gejala alam secara sistematis, sehingga IPA bukan hanya kumpulan penguasaan pengetahuan berupa fakta-fakta, konsep-konsep, atau prinsip-prinsip saja, tetapi juga merupakan suatu proses penemuan. Pendidikan IPA diharapkan dapat menjadi wahana bagi peserta didik untuk mempelajari diri sendiri dan alam sekitar, serta prospek pengembangan lebih lanjut dalam menerapkannya dalam kehidupan sehari-hari (Trianto, 2010). Kimia merupakan ilmu yang termasuk rumpun IPA, oleh karenanya kimia mempunyai karakteristik sama dengan IPA. Hakikat ilmu kimia sebagai bagian dari IPA mencakup dua hal yang tidak terpisahkan, yaitu kimia sebagai produk dan kimia sebagai proses (Alman, 2010).

Kurikulum Tingkat Satuan Pendidikan menyebutkan bahwa pembelajaran kimia bertujuan untuk memperoleh pengalaman dalam menerapkan metode ilmiah melalui percobaan atau eksperimen, dimana peserta didik melakukan pengujian hipotesis dengan merancang percobaan melalui pemasangan instrumen, pengambilan, pengolahan dan penafsiran data, serta menyampaikan hasil percobaan secara lisan dan tertulis. Perubahan penekanan dari perolehan pengetahuan kepada perolehan sains itu karena adanya asumsi bahwa belajar yang terbaik adalah melalui pengalaman (Arifin et.al, 2000). 
Keterampilan Proses Sains (KPS) mendukung terciptanya kimia sebagai proses dan produk. KPS menuntut siswa berpikir dan bertindak untuk menghadapi atau merespon masalah-masalah yang ada di lingkungan. Jadi, kimia sebagai proses menyangkut proses atau cara kerja untuk memperoleh hasil (produk) inilah yang kemudian dikenal sebagai proses ilmiah. Merujuk pada pernyataan itu, maka keterampilan proses sains dipandang sebagai keterampilan yang sangat penting dimiliki oleh setiap siswa untuk memperoleh pengetahuan sains. Dengan mengembangkan keterampilan proses, anak akan mampu menemukan dan mengembangkan sendiri fakta dan konsep serta menumbuhkan dan mengembangkan sikap dan nilai yang dituntut (Semiawan et.al, 2003)

Keterampilan Proses sains juga mendukung tujuan pembelajaran kimia di SMK. Salah satu tujuan mata pelajaran kimia di SMK yaitu menerapkan metode ilmiah melalui percobaan atau eksperimen, dimana peserta didik melakukan pengujian hipotesis dengan merancang percobaan melalui pemasangan instrumen, pengambilan, pengolahan dan penafsiran data, serta menyampaikan hasil percobaan secara lisan dan tertulis. Implikasinya adalah pembelajaran kimia di SMK hendaknya bersifat kontekstual, aplikatif dan terintegrasi dengan bidang keahliannya.

Fakta di SMKN Kehutanan Pekanbaru memperlihatkan bahwa dalam mempelajari sains, siswa cenderung lebih menghafal konsep, teori, dan prinsip tanpa memaknai proses perolehannya. KSP belum terlihat pada pembelajaran di SMKN Kehutanan. Selama pembelajaran di kelas, siswa tidak berperan aktif. Siswa hanya memperhatikan dan mendengarkan penjelasan materi serta menghafalnya saja tanpa diberikan kesempatan untuk mencoba menemukan sendiri pengetahuan tersebut. Selain itu, cara mengajar guru hanya terpaku pada buku saja tanpa menghubungkannya dengan pengetahuan dan pengalaman siswa dalam kehidupan sehari-hari sehingga relevansi pendidikan kimia dengan kebutuhan lingkungan siswa tidak tercapai.

Permasalahan keterampilan proses sains juga menjadi salah satu penyebab yang mempengaruhi kemampuan berpikir kreatif siswa. Penerapan keterampilan proses sains menjadi salah satu pilihan dalam pembelajaran untuk meningkatkan kreativitas siswa. KPS terdiri dari beberapa aspek yang harus dilewati dan dikuasai oleh siswa yaitu memprediksi, mengelompokkan, menerapkan konsep, berkomunikasi, observasi dan merancang percobaan. Seorang guru harus bisa memilih serta menerapkan model 
pembelajaran yang tepat untuk dapat mengembangkan dan meningkatkan keterampilan serta kemampuan berpikir siswa dalam pengetahuannya. Model pembelajaran merupakan suatu pola yang digunakan sebagai pedoman dalam merencanakan pembelajaran di kelas atau pembelajaran dalam tutorial dan untuk menentukan perangkat-perangkat pembelajaran seperti buku, film, komputer, kurikulum, dan lainlain.

Berdasarkan penjelasan tersebut, maka diperlukan suatu pembelajaran yang dapat mengembangkan KPS serta penguasaan konsep siswa. Model pembelajaran berbasis proyek merupakan model pembelajaran yang berpusat pada keaktifan siswa (student center learning), guru belajar dari dan bersama siswa. Selama pembuatan proyek, siswa bisa melatih dan mengembangkan keterampilan proses sains mereka yaitu seperti mengamati, menggunakan alat dan bahan, menginterpretasikan, merencanakan proyek, menerapkan konsep, mengajukan pertanyaan dan berkomunikasi dengan baik.

Pembelajaran yang memungkinkan terlaksananya hal-hal tersebut salah satunya pembelajaran dengan model proyek. Adapun yang dimaksud dengan pembelajaran proyek ialah salah satu cara pemberian pengalaman belajar dengan menghadapkan anak dengan persoalan sehari-hari yang harus dipecahkan secara berkelompok (Wena, 2009). Semiawan (dalam Wena, 2009) mengatakan bahwa sebelum melaksanakan proyek dalam pembelajaran, siswa harus telah memiliki pengetahuan awal yang berkaitan dengan tugas-tugas yang dikerjakan.

Pembelajaran berbasis proyek sebagai salah satu metode pembelajaran baru dan sebagai asesmen alternatif telah banyak dikembangkan, diantaranya oleh Sola dan Ojo (2007) yang menerapkan pembelajaran proyek dalam praktikum pemisahan campuran untuk melihat peningkatan hasil belajar siswa. Maros (2004), Adami (2006), Butter (2009), serta Mascotti dan Warner (2010) mengembangkan metode proyek untuk mengukur penguasaan konsep. Morgil (2008), menerapkannya dalam melihat sikap siswa terhadap kimia. Purnamasari (2011), menerapkannya untuk meningkatkan motivasi belajar siswa SMKN pada pembelajaran pengolahan makanan. Hal ini dapat bermanfaat bagi mereka dalam memperoleh "life skills" yang sangat penting untuk bekal kehidupannya di masa depan ketika mereka dihadapkan pada masalah-masalah lain. Karakteristik ini menjadikan hasil pembelajaran dalam sains bukan hanya sekedar mengetahui sekumpulan pengetahuan yang berupa fakta, konsep, prinsip atau teori saja, 
tetapi diharapkan dapat menjadi wahana bagi peserta didik untuk mempelajari diri sendiri dan alam sekitarnya serta prospek pengembangan berbagai kemampuan atau keterampilan lebih lanjut. Hal ini sejalan dengan tuntutan yang tercantum dalam Standar Kompetensi Lulusan (SKL) kimia di SMK.

Materi pemisahan campuran dalam mata pelajaran kimia di SMK, termasuk ke dalam materi yang penting untuk dikuasai siswa baik secara konseptual maupun secara praktikal. Materi ini sangat mendukung bidang keahlian siswa, sehingga dalam proses belajar mengajar guru diharapkan mampu membantu siswa untuk memahami materi sekaligus memfasilitasi siswa agar mampu mempraktekkannya secara langsung dan kontekstual sesuai dengan bidang keahliannya. Materi pemisahan campuran berkenaan dengan materi dasar dan integrasi, filtrasi, kristalisasi, kromatrografi dan distilasi. Implikasinya, metode proyek merupakan metode yang diduga kuat relevan untuk digunakan dalam pembelajaran pada konsep pemisahan campuran.

\section{METODE PENELITIAN}

Metode penelitian yang digunakan adalah Weak Experimental. Metode tersebut digunakan karena metode ini merupakan metode yang paling sesuai dengan kondisi subjek penelitian, dimana kelas yang diteliti hanya satu kelas dan tidak menggunakan kelas pembanding.

Desain yang digunakan dalam penelitian ini adalah One Group Pre-test-Postest Design (Frankel dan Wallen, 2008). Desain ini digunakan untuk penentuan peningkatan penguasaan konsep dan peningkatan KPS. Materi pemisahan campuran dilakukan dengan 3x pertemuan.

Subjek dalam penelitian ini adalah siswa kelas X SMKN Kehutanan Provinsi Riau pada semester II tahun ajaran ajaran 2011/ 2012 yang berjumlah 30 orang. Pemilihan kelas X sebagai subjek penelitian dilakukan atas pertimbangan bahwa materi pemisahan campuran dipelajari di kelas $\mathrm{X}$, ini berdasarkan sebaran $\mathrm{KD}$ yang disusun oleh pihak sekolah.

Instrumen yang digunakan untuk memperoleh data dalam penelitian adalah tes tertulis pilihan ganda yang digunakan untuk mengukur penguasaaan konsep siswa dan soal essay yang digunakan untuk mengukur keterampilan proses sains siswa. Adapun alur dari penelitian pembelajaran berbasis proyek ini dapat dilihat pada Gambar 1. 


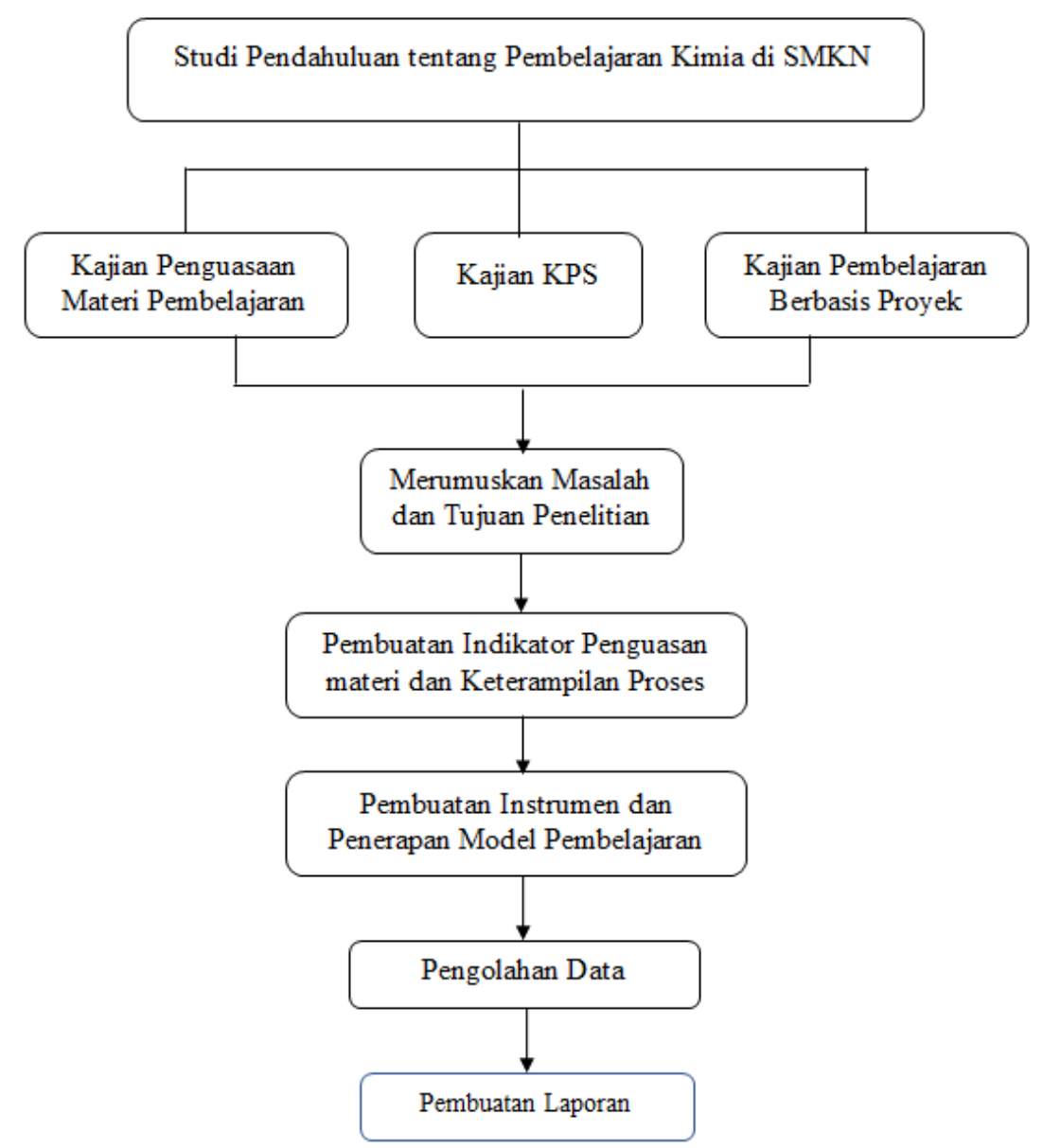

Gambar 1. Alur penelitian pembelajaran berbasis proyek

\section{Analisis data}

Data penelitian berupa hasil tes tertulis dianalisis melalui tahapan berikut:

a) Menentukan skor dari setiap jawaban hasil tes (pre-test dan post-test)

b) Menghitung skor total tiap siswa dan skor tiap butir soal.

c) Menghitung nilai pre-test dan post-test setiap siswa dengan rumus:

$$
\text { Nilai siswa }=\frac{\text { Skor mentah }}{\text { Skor maksimal }} \times 100
$$

d) Menghitung persentase KPS dan peningkatan penguasaan konsep siswa yang terjadi sebelum dan sesudah pembelajaran dihitung dengan menggunakan gain yang dinormalisasi yaitu denganrumus $g$ faktorsebagai berikut: 


$$
\text { Persentase }<g>=\frac{<S_{\text {post }}>-<S_{\text {pre }}>}{<S_{\text {maks }}>-<S_{\text {pre }}>} \times 100 \%
$$

Keterangan:

$\langle g\rangle \quad=$ rata-rata gain yang dinormalisasi

$\left\langle\mathrm{S}_{\text {post }}\right\rangle=$ nilai post-test

$\left\langle\mathrm{S}_{\text {pre }}\right\rangle \quad=$ nilai pre-test

$\left\langle\mathrm{S}_{\text {maks }}\right\rangle=$ nilai maksimum ideal

Untuk mengkategorikan persentase $\langle g\rangle$ penguasaan konsep siswa digunakan pengkategorian yang dapat dilihat pada Tabel 1 .

Tabel 1. Pengkategorian Persentase $\langle\mathrm{g}>$

\begin{tabular}{cc}
\hline Persentase & Kategori \\
\hline$\%<g>>70,0$ & Tinggi \\
\hline $30,0 \leq \%<g>\leq 70,0$ & Sedang \\
\hline$\%<g><30,0$ & Rendah \\
\hline
\end{tabular}

\section{HASIL DAN PEMBAHASAN}

Pada bagian ini akan disajikan hasil pengolahan data berkenaan dengan penerapan pembelajaran berbasis proyek terhadap peningkatan KPS dan penguasaan konsep siswa dan pembahasannya.

HASIL

\section{Penguasaan KPS}

Analisis data KPS dilakukan untuk mengetahui peningkatan KPS siswa pada pertemuan ke 1 dan pertemuan ke 3. Pada pertemuan ke 2 materi pemisahan campuran berkaitan dengan teori kromatografi dan distilasi, pada topik ini tidak dilakukan penilaian KPS. Pada Gambar 2 dapat dilihat setiap aspek KPS pada pertemuan ke-1 dan pertemuan ke-3. 


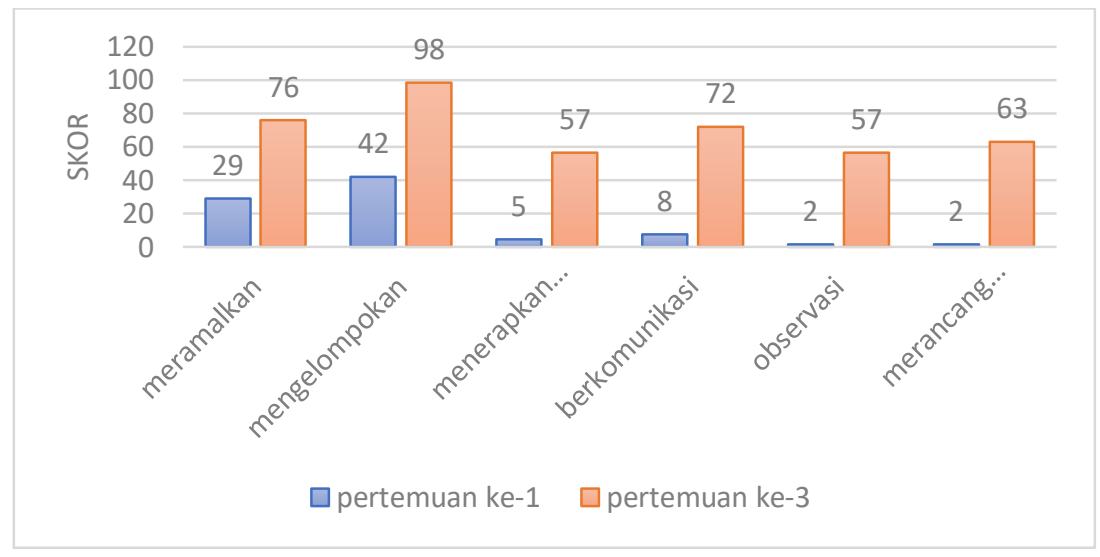

Gambar 2. Grafik Peningkatan KPS Siswa

Peningkatan KPS siswa secara detail dapat dikelompokkan untuk setiap jenis keterampilan proses sains yaitu, keterampilan memprediksi, mengelompokkan, menerapkan konsep, berkomunikasi, observasi, dan merancang percobaan. Presentase peningkatan KPS terlihat pada Gambar 3.

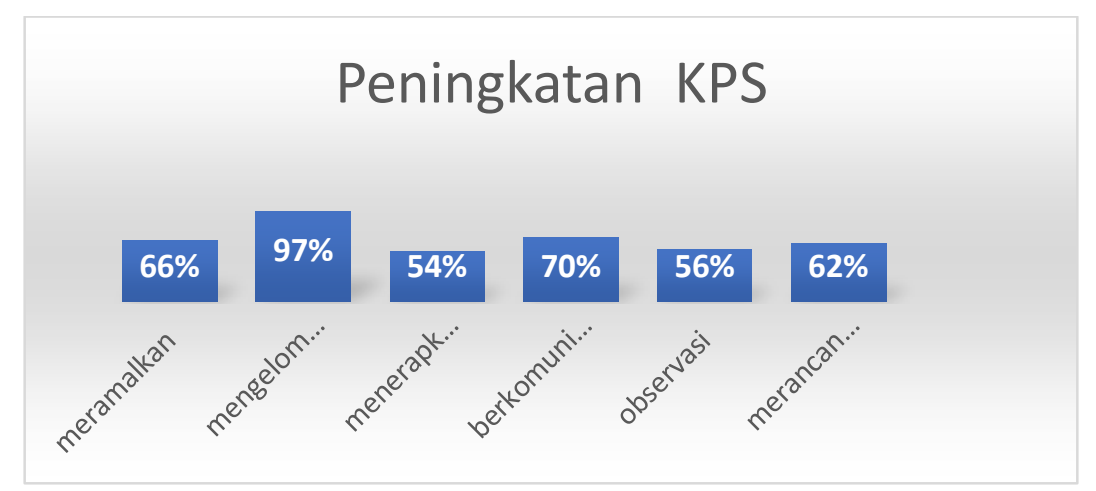

Gambar 3. Persentase Peningkatan KPS

Secara lebih khusus, nilai rata-rata peningkatan keterampilan proses sains siswa melalui perhitungan untuk masing-masing aspek KPS akan dirinci lebih dalam untuk perolehan siswa berdasarkan kategori tinggi, sedang dan rendah yang dapat dilihat pada Tabel 3.

Tabel 3. Skor Observasi Aspek KPS

\begin{tabular}{lll}
\hline Aspek KPS & Kategori & Presentase Siswa \\
\hline \multirow{2}{*}{ Memprediksi } & Tinggi & $46,7 \%$ \\
\cline { 2 - 3 } & Sedang & $26,7 \%$ \\
\cline { 2 - 3 } & Rendah & $26,7 \%$ \\
\hline
\end{tabular}




\begin{tabular}{lll}
\hline Aspek KPS & Kategori & Presentase Siswa \\
\hline \multirow{2}{*}{ Mengelompokkan } & Tinggi & $70,0 \%$ \\
\cline { 2 - 3 } Menerapkan Konsep & Sedang & $3,3 \%$ \\
\cline { 2 - 3 } & Rendah & $26,7 \%$ \\
\hline \multirow{3}{*}{ Berkomunikasi } & Sedang & $30,0 \%$ \\
\cline { 2 - 3 } & Rendah & $43,3 \%$ \\
\hline \multirow{2}{*}{ Observasi } & Tinggi & $26,7 \%$ \\
\cline { 2 - 3 } & Sedang & $43,3 \%$ \\
\cline { 2 - 3 } & Rendah & $43,3 \%$ \\
\hline \multirow{2}{*}{ Merancang Percobaan } & Tinggi & $13,3 \%$ \\
\cline { 2 - 3 } & Sedang & $36,7 \%$ \\
\cline { 2 - 3 } & Rendah & $43,3 \%$ \\
\cline { 2 - 3 } & Tinggi & $20,0 \%$ \\
\cline { 2 - 3 } & Redang & $50,0 \%$ \\
\hline & & $26,7 \%$ \\
\hline
\end{tabular}

\section{Penguasaan Konsep Pemisahan Campuran}

Untuk mengetahui apakah penerapan pembelajaran proyek memberikan pengaruh terhadap penguasaan konsep siswa pada pemisahan campuran, maka dilakukan analisis data pre-test dan post-test yang diperoleh siswa, kemudian menentukan peningkatan penguasaan konsep melalui perhitungan $\langle\mathrm{g}\rangle$. Berdasarkan hasil pengolahan data tes penguasaan konsep siswa, secara umum dapat ditunjukkan pada Gambar 4.

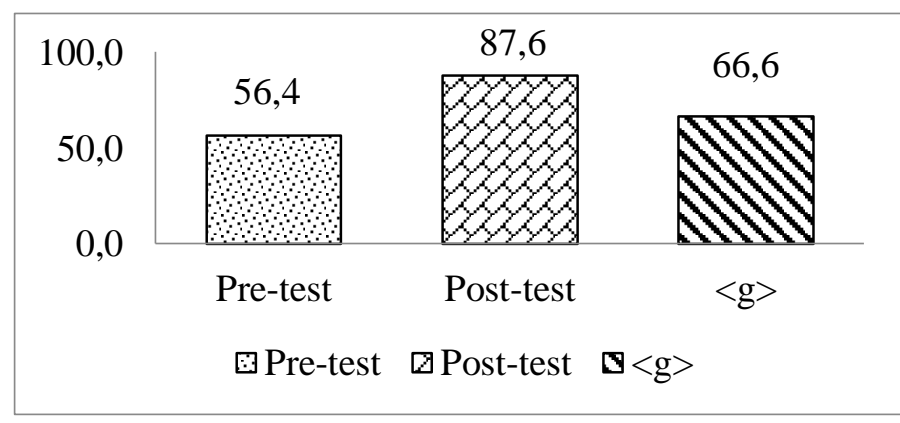

Gambar 4. Penguasaan Konsep Siswa secara Keseluruhan sebelum (pre test) dan sesudah (post-test) pembelajaran. 
Gambar 4 menunjukkan nilai rata-rata pre-test, nilai rata-rata post-test, dan persentase $\langle\mathrm{g}>$ penguasaan konsep yang dicapai siswa pada materi pemisahan campuran dengan penerapan pembelajaran berbasis proyek. Pada tes awal, siswa memperoleh nilai rata-rata sebesar 56,4. Setelah proses belajar-mengajar berlangsung penguasaan konsep siswa cenderung meningkat. Hal ini terlihat dari nilai rata-rata posttest penguasaan konsep yang diperoleh oleh siswa yaitu sebesar 87,6. Peningkatan penguasaan konsep siswa sebelum dan setelah pembelajaran sangat erat kaitannya dengan $\langle$ g $>$. Hal ini menunjukkan bahwa penguasaan konsep siswa secara keseluruhan pada materi pemisahan campuran meningkat dengan kategori sedang setelah pembelajaran berbasis proyek. Lebih rinci, dapat dilihat pada Tabel 4.

Tabel 4. Kategori $(<\mathrm{g}>)$ pada penguasaan konsep

\begin{tabular}{lll}
\hline Sub konsep & Kategori $\langle\mathbf{g}\rangle$ & Presentase Siswa \\
\hline \multirow{2}{*}{ Dasar dan integrasi } & Tinggi & $50 \%$ \\
\cline { 2 - 3 } & Sedang & $33 \%$ \\
\cline { 2 - 3 } Filtrasi & Rendah & $17 \%$ \\
\hline \multirow{3}{*}{ Kristalisasi } & Tinggi & $37 \%$ \\
\cline { 2 - 3 } & Sedang & $10 \%$ \\
\cline { 2 - 3 } & Rendah & $53 \%$ \\
\hline \multirow{3}{*}{ Kromatografi } & Tinggi & $53 \%$ \\
\cline { 2 - 3 } & Sedang & $70 \%$ \\
\cline { 2 - 3 } & Rendah & $50 \%$ \\
\hline & Tinggi & $13 \%$ \\
\cline { 2 - 3 } Distilasi & Sedang & $37 \%$ \\
\cline { 2 - 3 } & Rendah & $57 \%$ \\
\hline & Tinggi & $43 \%$ \\
\cline { 2 - 3 } & Sedang & $0 \%$ \\
\cline { 2 - 3 } & Rendah & $40 \%$ \\
\hline & & \\
\hline
\end{tabular}

\section{PEMBAHASAN}

Berdasarkan hasil penelitian di atas dapat terlihat bahwa penerapan pembelajaran berbasis proyek mampu meningkatkan penguasaan konsep siswa secara 
keseluruhan. Walaupun demikian masih terdapat 2-3 orang siswa yang tidak mengalami peningkatan secara signifikan. Nilai mereka hanya meningkat 10-15 poin, sedangkan siswa yang lainnya mengalami peningkatan secara siknifikan. Hal ini terjadi karena faktor dari individu itu sendiri, seperti tidak fokus saat belajar, tidak serius dalam mengikuti pembelajaran.

Penerapan pembelajaran berbasis proyek berhasil meningkatkan penguasaaan konsep dasar pemisahan campuran, filtrasi, kristalisasi, kromatografi dan distilasi. Melalui kerja proyek siswa dapat belajar konsep utama dari suatu pengetahuan. Sejalan dengan pendapat Semiawan et.al (2003), yang mengemukakan bahwa strategi proyek bertujuan untuk memantapkan pengetahuan yang dimiliki siswa, serta memungkinkan siswa memperluas wawasan pengetahuannya.

Guru harus mampu mengaitkan pengalaman keseharian siswa atau konsepkonsep yang telah ada pada siswa untuk meningkatkan pemahaman dan penguasaan pada diri siswa, ini dapat dilakukan melalui pembelajaran berbasis proyek. Sejalan dengan pendapat Wena (2009), dalam pembelajaran berbasis proyek siswa mengalami dan belajar konsep-konsep inti suatu disiplin ilmu melalui proyek. Melalui proyeknya, siswa dapat menemukan sendiri pengetahuan tersebut. Mereka bekerja dan berusaha untuk memecahkan masalah, menerapkan dan membangun pengetahuan, menemukan sesuatu untuk dirinya dengan berusaha melalui ide-idenya.

Sejalan dengan pendapat Slavin (dalam Trianto, 2010) yang mengatakan bahwa salah satu prinsip yang paling penting dalam psikologi pendidikan adalah bahwa guru tidak hanya sekedar memberikan pengetahuan kepada siswa, namun siswa harus membangun sendiri pengetahuan di benaknya. Menurut teori konstruktivis, belajar bermakna tidak akan terwujud hanya dengan mendengarkan ceramah atau membaca buku tentang pengalaman orang lain atau buku perpustakaan. Implikasinya, melalui pembelajaran proyek guru dapat memberikan kemudahan untuk proses tersebut dengan cara memberikan kesempatan kepada siswa untuk menemukan dan menerapkan ide-ide mereka dalam menyelesaikan tugas proyek, sehingga secara tidak langsung mereka dapat menggunakan strategi mereka sendiri untuk belajar.

Dengan pembelajaran proyek, siswa dapat menerapkan pengetahuan mereka dalam kehidupan sehari-hari atau terhadap permasalahan yang terkait sehingga penguasaan mereka terhadap suatu konsep akan lebih meningkat. Hal ini sejalan dengan pendapat 
Dahar (1996) yang mengungkapkan bahwa penguasaan konsep tidak hanya terbatas mengenal konsep saja namun siswa tersebut juga harus mampu memahami suatu permasalahan baik konsep secara teori maupun penerapannya dalam kehidupan seharihari. Selain itu, peningkatan yang terjadi juga disebabkan karena pembelajaran berbasis proyek memiliki beberapa kelebihan seperti yang dikemukakan oleh Moursund (dalam Wena, 2009) antara lain sebagai berikut:

a. Meningkatkan motivasi belajar siswa terbukti dari beberapa laporan penelitian tentang pembelajaran berbasis proyek yang menyatakan bahwa siswa sangat tekun, berusaha keras untuk menyelesaikan proyek, siswa merasa lebih bergairah dalam pembelajaran, dan keterlambatan dalam kehadiran sangat berkurang.

b. Membuat siswa menjadi lebih aktif dan memecahkan problem-problem yang bersifat kompleks.

c. Memberikan kesempatan kepada siswa untuk mempraktikkan apa yang telah dipelajari.

d. Meningkatkan keterampilan siswa dalam mencari dan mendapatkan informasi.

e. Meningkatkan dan mengembangkan keterampilan komunikasi siswa.

f. Pembelajaran berbasis proyek yang diimplementasikan secara baik memberikan kepada siswa pembelajaran dan praktik dalam mengorganisasi proyek dan membuat alokasi waktu.

Aspek KPS siswa yang mengalami peningkatan tertinggi yaitu aspek mengelompokkan sebesar 97\%, sedangkan terendah dicapai pada aspek menerapkan konsep sebesar 54\%. Terjadi peningkatan penguasaan konsep pemisahan campuran sebesar 66,6\% dengan kategori sedang. Dengan demikian terlihat bahwa penguasaan konsep materi diperoleh dengan adanya proses. Pembelajaran proyek mengajarkan siswa untuk memahami dan menjalani proses, sehingga penguasaan konsep merupakan salah satu dampak dari adanya keterampilan dalam menjalankan proses tersebut. Kategori sedang $(66,6 \%)$ pada peningkatan penguasaan konsep ini juga sama halnya dengan peningkatan KPS aspek penerapan konsep (54\%) yang merupakan presentase yang terendah dari semua aspek pada KPS.

Pada penelitian ini diperoleh peningkatan KPS aspek komunikasi $70 \%$ kategori tinggi, hal ini sesuai dengan temuan Trianto (2010) yang mengatakan bahwa siswa akan lebih mudah menemukan dan memahami konsep-konsep yang sulit apabila mereka 
dapat saling mendiskusikan masalah-masalah itu dengan temannya. Hal ini berkaitan dengan keterampilan proses sains pada aspek keterampilan berkomunikasi. Untuk peningkatan KPS aspek observasi 56\% kategori sedang. Para ahli kontruktivis juga beranggapan bahwa satu-satunya alat yang tersedia bagi seseorang untuk mengetahui dan memahami sesuatu adalah inderanya karena sesorang berinteraksi dengan objek dan lingkungannya dengan melihat, mendengar, mencium, menjamah, dan merasakannya. Implikasinya, hal tersebut berkaitan dengan salah satu aspek dari KPS yakni keterampilan observasi.

Selain itu, keterampilan-keterampilan lainnya juga mendukung siswa dalam memahami suatu konsep dengan lebih baik. Sejalan dengan pendapat Semiawan et.al (2003) yang menyatakan bahwa dengan mengembangkan keterampilan proses, anak akan mampu menemukan dan mengembangkan sendiri fakta dan konsep serta menumbuhkan dan mengembangkan sikap dan nilai yang dituntut.

\section{KESIMPULAN}

Berdasarkan hasil penelitian dan analisis, dapat disimpulkan bahwa pembelajaran berbasis proyek pada materi pemisahan campuran dapat meningkatkan KPS siswa. Sejalan dengan meningkatnya KPS siswa, penerapan pembelajaran berbasis proyek berimplikasi terhadap peningkatan penguasaan konsep. Seluruh aspek dalam penguasaan konsep pada materi pemisahan campuran meningkat.

\section{DAFTAR PUSTAKA}

Adami, G, 2006, A New Project-Based Lab for Undergraduate Enviromental and Analytical Chemistry, Journal of Chemistry Education, 83 (2)

Alman, 2010, Pedoman Workshop KTSP SMKN Pertanian Terpadu Negeri Provinsi Riau_KTSP SMKN, Departemen Pendidikan Nasional

Arifin, M., Sudja, W.A., Ismail, A.K., Mulyono. dan Wahyu, W, 2000, Strategi Belajar Mengajar Kimia, Pendidikan Kimia FPMIPA UPI, Bandung

Butter, L.R, 2009, Investigation of The Use of Cucumis Sativus for Remediation of Chromium from Contaminated Environmental Matrices. An Interdiciplinary Instrumental Analysis Project, Journal of Chemistry Education, 86 (9) 
Frankel, J. P. dan Wallen N. E., 2008, How to Design and Evaluate Research in Education. New York : McGraw-Hill Companies

Morgil, I., 2008, “The Effect of Web-Based Project Applications on Students' Attitudes Towards Chemistry'. Journal of Distance Education-TODJE Volume 9.

Purnamasari, E., 2011, Upaya Peningkatan Motivasi Belajar Siswa Melalui Penerapan Metode Berbasis Proyek pada Mata Pelajaran Pengolahan Makanan di SMK Sahid Surakarta, Thesis Universitas Negeri Yogyakarta.

Maros, P.S., 2004, Class Project in Physical Organic Chemistry : The Hydrolysis of Aspirin, Journal of Chemistry Education, 81 (6)

Mascotti, D.P, dan Warner, M.J, 2010, Complementary Spectroscopic Assays for Investigating Protein-Ligand Binding Activity : A Project for The Advanced Chemistry laboratory. Journal of Chemistry Education, 87 (7)

Semiawan, C., Tangyong, A.F., Belen, S., Matahelemual, Y, 2003, Pendekatan Keterampilan Proses; Bagaimana Mengaktifkan Siswa dalam Belajar, PT. Gramedia, Jakarta

Sola dan Ojo, 2007, Effects of Project, Inquiry, and Lecture-Demonstration Teaching Methods on Senior Secondary Students' Achievement in Separation of Mixtures Practical Test, Journal of Educational Research and Review vol.2 (6)

Trianto, 2010, Model Pembelajaran Terpadu : Konsep, Strategi, dan Implementasinya dalam KTSP. Bumi Aksara, Jakarta

Wena, M, 2009, Strategi Pembelajaran Inovatif Kontemporer, Bumi Aksara, Jakarta 